\title{
AN ESSAY ON THE SENSORY AND THE (POTENTIAL) END OF HERITAGE MAKING
}

\author{
REGINA F. BENDIX
}

The expansion from material heritage-pleasing sight and to a lesser extent touch (for very often material heritage may be touched only within limits) - to the realm of the intangible indicates an increase in the reflexive consideration of the full sensorium. With the ratification of the 2003 Intangible Heritage Convention, we have turned to select for heritage status cultural practices and perceptions entailing the body and the senses more fully: music and dance, as well as craft traditions exemplifying the knowledge in hands and the skill of touch. The new French sensory heritage law could be a significant marker in the changing dynamic of valorizing selected aspects of culture.

Keywords: sensory heritage, law, France, gastronomy, intangible heritage
Širitev z materialne dedišcine - všsečnega pogleda in nekoliko manj taktilnega (sajse je materialne dedišcine mogoče dotakniti le omejeno) - na področje nesnovne kaže na rast refleksivne obravnave polno cutnega. Z ratifikacijo Konvencije o nesnovni dediščini iz leta 2003 so pridobile status dediščine kulturne prakse in zaznave, ki v celoti vključujejo telo in čute: glasbo in ples, pa tudi obrtne tradicije, ki ponazarjajo ročno znanje in spretnost dotika. Novi francoski zakon o senzorični dedišcini bi labko bil pomemben označevalec v spreminjajoči se dinamiki vrednotenja izbranih vidikov kulture. Ključne besede: dediščina čutov, zakon, Francija, gastronomija, nesnovna dedišcina

In 2019, rooster Maurice made for a splash in the international press. A French court threw out a case launched against him or rather his owner by newcomers to a rural setting. These second home owners had not appreciated Maurice's contribution to the agrarian sound scape. They had purchased a holiday home expecting peace and quiet in a bucolic setting. Landscapes, alas, are populated and the ocularcentric new homeowners fleeing the city were confronted with the sounds of domesticated animal life. The case was meant to silence Maurice, but instead, Maurice and his barnyard friends, from mooing cows to bleating sheep, contributed to a new French law that protects sounds and smells in the countryside. The "Sensory Heritage Law" blocks further lawsuits of the type that targeted Maurice, ${ }^{1}$ and it extends to the smell of pig sties, the babbling of ducks, and the ringing of church bells. “'Living in the countryside implies accepting some nuisances,' Joël Giraud, the government's minister in charge of rural life, told lawmakers" (Anon. 2021) - making a step not simply toward saving a rooster and his rural kin, but also toward opening the floodgates of patrimonialization of life in all its atmospheric notes.

The French sensory heritage law could be a significant marker in the changing dynamic of valorizing selected aspects of culture. Optimistically put, the French legislature's

1 Reports about France's new law appeared in the international press, e.g., AFP/kmi 2021; Anon. 2021. 
engagement with rooster Maurice represents a sensible step toward accepting life as lived in its totality. My brief, exploratory essay will trace the value-additions inserted in successive elements of this totality, pointing occasionally to their intertwining with the sensorium and the hierarchies of value that the senses, in turn, have been subjected to. ${ }^{2}$ Economic interests and cultural policies, such as the tourist industry and heritage conventions, grew out of an increased (not only but also scholarly) interest in identifying and interpreting cultural difference. As the understanding of culture expands from the particularity of human-made elements and practices to the web of relations beyond the human, the regulatory systems in place to extract value from culture might be reaching their peak and perhaps tilt, eventually, to allow us to focus our energies to where they are needed more: the climate crisis and what is needed to permit roosters to continue crowing, and the multispecies web to find a sustainable future.

Let us start with the touristic onset of tailoring culture to suit guests' needs. Sensory patrimony and its legal protection would seem to constitute a full turn-around in the dynamics of the tourist trade. There was a time, as of the turn from the $19^{\text {th }}$ to $20^{\text {th }}$ century, when mayors of alpine villages caved in to the pressure of hotel owners: church bells were silenced for the night and public fountains turned off, as tourists complained about such nighttime disturbances. The wishes of guests were to be accommodated at all costs, following the proverbial principle that guests are to be treated like royalty. ${ }^{3}$ The majesty of mountain landscapes was what early visitors sought; they had to be protected from the noise of an agrarian underclass. Travelers and later on steadily growing numbers of tourists allowed for the growth of the hospitality industry in many regions. The increased number of guests found a parallel in the decreasing number of inhabitants who were drawn by industrial employment in urban areas since the mid- to late $19^{\text {th }}$ century. For many depopulating areas, second home owners have been a welcome addition since the 1960s, in many places even earlier. Some of them buy houses that have been standing empty and renovate them, and often it is particularly the opportunity to contribute to the maintenance of traditional house types that is attractive to them. ${ }^{4}$ It gives them a chance to dwell within structures showing patrimonial appeal in their very materiality, enhancing the contrast to what these second home owners perhaps inhabit for the better part of the year, namely particularly efficient, late-modern, metropolitan first residences. The case

2 I am expanding here on Barbara Kirshenblatt-Gimblett's path breaking characterization of heritage as a value-added industry (1995), as the mechanism of selecting and adding value to particular aspects of everyday life and history extends back deeply into history, before the heritage apparatus gained its mindboggling speed.

3 At least in German, the proverb „Der Kunde ist König” ("the customer is the king”) is an iron principle in many branches of the hospitality industry.

4 Luis Silva (2014) has discussed the effort to alleviate rural depopulation with efforts to invest in the heritage fabric of local dwellings that simultaneously are to draw guests - and the double edged sword this can turn out to be. 
against Maurice indicates that it was still the visuals that were of particular appeal to the plaintiffs - much as it was the views, the opportunity to gaze, that stimulated the travelling nobility, and that increasingly controlled the first bourgeois tourists, and the subsequent waves of mass tourists (cf. Urry, 1990). They were equipped with brushes and pencils and later on cameras, and the images they captured and shared at home were views, carried by the sense of sight, the sense most celebrated since the Enlightenment, not least because of its purported truthfulness. Intellectually as well as socially, it would take a long time for the "lower senses" - with smell generally featuring at the bottom - to be reconsidered. Sound, although generally considered quite positively, was nonetheless ambiguous: for one, the nature and (class-based) source of sound needed to be differentiated: for another, unlike visuals that could be captured, sound remained, apart from notation, evanescent far into the $19^{\text {th }}$ century (Bendix, 2000; Projektgruppe Zuhören, 2003).

Second-home owners are not simply guests. They may be subjected to taxation, and in turn they expect road improvement as well as other infrastructural work. But the case of Maurice demonstrates that for some regular, livelong inhabitants, a limit has been reached with regard to accommodating to new-comers' expectations. Indeed, witnessing the filing of a lawsuit against a rooster may have been what was needed to stand up against the social inequalities on which mobile, multi-local home ownership rests. ${ }^{6}$ The attempt at disciplining a rooster's crowing thus generated, beyond a court battle, a legislative effort built on what one might term regulating via heritage law not just neighborly relations but also the sense of entitlement of mobile cosmopolitans to fashion the world to their particular preferences.

Successful heritage inscriptions have, indeed, repeatedly been used to exert social control. Peasants around the world heritage site of Angkor in Cambodia are asked to build traditional farm dwellings rather than corrugated sheet metal shacks. The latter are quickly built and affordable for expanding families, but they might offend the tourist gazing upon the whole of the heritage site; correspondingly, the heritage police intervenes when building infractions occur (Miura, 2011: 28). Windmills remain unbuilt so as not to spoil the view onto and from a full heritage ensemble, and architects have to curb their imagination to harmonize with UNESCO certified heritage fabric in various cities (Bendix, 2009). The intangible heritage framework has equally ignited tradition bearers to defend their traditional trades and festive events against unwelcome participants or thievish appropriations - leading, beyond efforts at heritage inscriptions, to legal and moral conundrums that bring forth unforeseen pain into social arrangements (Noyes, 2016a). As Valdimar Hafstein has

5 Madalina Diaconu (2013) has offered a concise overview of the philosophical discussions regarding the senses, among which Baumgarten (1961 [1750]) is perhaps one of the most comprehensive, early treatise.

6 Daniela Seidl (2007: 110), referring to Ulrich Beck's "transnational place-polygamy" (1997: 129), points to the drawing of distinctions inherent to second-home dwelling practices. The possibility to have two homes and to relish the social advantage it rests on has been part of social history literally "for thousands of years" (Bendix, Löfgren, 2007: 8). 
argued, intangible heritage making and the safeguarding provisions that accompany it, just as a matter of course bring forth a sequence of reforming measures that straighten up the practices, and heighten the self-reflexivity of the practitioners themselves (Hafstein, 2018: 128-129). As welcome and enlightening as self-reflection may be, it is also a burden that interferes with simply carrying on with life. Illustrated with the example of Maurice: once the rooster's crowing is identified as a segment of rurality that may be appreciated or - in the case of second-home dwellers - not, and once it is not simply a matter of hollering at the offending fowl but filing a lawsuit, the crowing stops to be simply a habitual part of the everyday atmosphere. It draws attention, generates administrative paper work, accumulates costs, and wrests attention from other matters one might have more reason to be focused on.

Hafstein (2018: 128) points to Ulrich Beck, Anthony Giddens and Scott Lash's notion of reflexive modernization (1994) as one of the culprits that has encouraged the close inspection of all our doings both for their risk, and, I would add, for their profit. Perhaps not overtly part of the heritage fold, but rapidly increasing on many continents and thus also a growing focal point of interest in ethnographic work are extractivist industries (Jacka, 2018) which to me, in their global asymmetries and phenomenal drive, bear a ghostlike semblance to the valorization of extracts of culture. The sequence of UNESCO's international heritage conventions established since 1972, with the parallel thickening of regional and national instruments, has, indeed, heightened everyday attention for tangible and intangible culture. This goes hand in hand with the increased mining of culture for both ideational and economic value. Mining forests, rivers, and underground tunnels impacts both environment and human health, and it often rests on exploiting working conditions. One might argue that phenomena and practices designated as heritage are far from the harshness that resonates even in the word extraction. Yet it may nonetheless be useful to use the term as a metaphor for how the heritage gaze has parsed "culture" past and present for potentially worthy morsels, from built landscapes and monuments to artisanal crafts, music traditions, children's games, and cookery. Once framed as a resource, and if successfully nominated for heritage status, such a cultural morsel finds itself, as Dorothy Noyes has observed, in "an enclave," it is "framed and sacred," with "the right to be but not the right to do. Although it generates economic activity around its edges, heritage itself is conceived as inert and defiled by change" (Noyes, 2016b: 399-400). This caged state, however, goes counter to how social actors constitute culture webs. To quote Arjun Appadurai:

Culture is not the inert ballast against which economic or political action is undertaken. It is also a scheme for action, a map of possibilities, and a tool for making new arrangements in the world. [...] It is the broad cosmological canvas that informs and underwrites action, both individual and collective, and provides a repertoire of values to imagine or constrain action. (Appadurai, 2020: x) 
No wonder, then, that around cultural morsels rendered inert by heritage, we have constructed an exceedingly busy cultural apparatus of identifying, selecting, competing, nominating, administering, and safeguarding. The vibrancy has moved to other types of cultural practices, informed by a canvas more bureaucratic and capitalist than cosmological.

It is here that we return to the sensorium and the perhaps mistaken hope I invest in France's sensory heritage law. Hafstein has broadened the semantics of the term "folklorization" to include in the gesture of heritage making the everyday appropriation of using scholarly knowledge, e.g., from folkloristics, to designate and interpret the very everyday life one lives (Hafstein, 2018: 139-141). In the past decades, researchers have turned with a vengeance to the cultural dimensions of sensory perception, ${ }^{7}$ and hence it should not surprise that the reflexive attention to sensory experience has also seeped into the heritage making apparatus. The expansion from material heritage - pleasing sight and to a lesser extent touch (for very often material heritage may be touched only within limits) - to the realm of the intangible indicates an increase in the reflexive consideration of the full sensorium. With the ratification of the 2003 Intangible Heritage Convention, we have turned to select for heritage status cultural practices and perceptions entailing the body and the senses more fully: music and dance, as well as craft traditions exemplifying the knowledge in hands and the skill of touch. With the onslaught of nominations in the realm of cookery since 2010, kicked off with traditional Mexican cuisine and the gastronomic meal of the French, taste and smell have rounded out the presence of the senses in their culturally molded aesthetic on the heritage list. ${ }^{8}$

The "loi visant à définir et protéger le patrimoine sensoriel des campagnes françaises" strikes me as different from the segmenting and valorizing reach of heritage conventions, for this law seeks to preserve or return to non-reflexivity in the realm of everyday doings, as is evident from a press report right after the legislation passed in January 2021: "The French countryside is now protected by law from attempts to stifle the everyday aspects of rural life by newcomers looking for peace and quiet, after French senators gave final approval to a 'sensory heritage' law." The text continues "Cow bells (and droppings), grasshopper or cicada chirps and noisy early-morning tractors are also now considered part of France's natural heritage that will be enshrined in environmental legislation" (rfi, 2021). The important difference between heritage and environmental legislation would seem to be that the latter enables villagers and livestock to go after their business without paying heed to the noises and smells they produce. For the "neo-rurals" as the second home owners are referred to in the press coverage, the ruling encourages examination of the nostalgic images

David Howes (2019) offers a condensed view into this rich field with a plethora of publications, many of which have also found a readership beyond academia and hence it should not surprise that they enter the field of heritage policy.

8 Raúl Matta (2016) and Jean-Louis Tornatore (2013) respectively for Peru and France demonstrate, how complex and socially as well as politically problematic the harnessing of a particular gustatory cultural practice and experience for a heritage listing is. 
they bring to the countryside, and commands an end to achieving their heart's desire via litigation at least when it comes to the everyday setting they have chosen for their holidays.

Maurice the rooster, sadly, passed away before France's sensory heritage law became a reality. But, perhaps, we will remember Maurice's early morning crowing as the starting noise toward making us embrace life itself, in its sensory totality in the past, the present, and foremost, the future.

Sensory heritage can be seen as a rapprochement between excessively enlightened and excessively capitalistic humans, their everyday life, and the debris of their history. After having undergone all the steps of heritagization with its "slow self-estrangement" (Noyes, 2016a: 362), the path may be open to reacquainting with habitus, that is, with simply internalizing the practices of everyday life within and beyond human relations. We may recover a way to relish this tacit knowledge, shaking off the burdens of framing, interpreting, valuing and valorizing all of its facets, tangible and intangible alike. Acknowledging that the smells and sounds of a given environment are as much part of the complex, interconnected web of planetary co-existence as are the visuals and the materiality of landscapes may move us forward to simply experience such intrinsic features of being alive. Sensory patrimony is, of course, still evidence of the excessive reflexivity which has brought about the value addition to excerpts of culture in the first place. The sensory dimensions of rural simplicity, furthermore, opens itself up for capitalization in myriad ways, as Dorothee Hemme (2010) showed in her tracing of the library of fragrances. Atmospheres, too, have already entered the realm of possible heritage consideration, with vigor for instance in architecture (Kepczynska-Walczak, Walczak, 2015), and with more reluctance in the realm of sensory theory (Fraigneau, 2021).

It may be too much to hope that a rooster's crowing might lead the way out of the thicket of metacultural or, rather, new cultural practices devised to select and administer heritage. For many, I am aware, the treatment of culture as a resource is a boon, allowing for direly needed economic gain, be this under the auspices of heritage and heritage tourism, or of another framework that enhances value and produces a reasonable price. ${ }^{9}$ But as a researcher, I allow myself for a while the vision that France's sensory heritage law constitutes the stroke of genius that liberates us from heritage making. It would be nice to imagine that there is no marketing opportunity in the noises and smells of animal husbandry, and that the new law forces the French, and us, to let go of reforming our relationship to ourselves in the never-ending loop of heritage-making.

9 The EU's system of geographic indications comes to mind immediately as a further road to niche market bolstering, see, e.g., May et al., 2017. 


\section{REFERENCES}

AFP/kmi. 2021. Hahnenschrei und Schafsblöken werden in Frankreich Kulturerbe. Berliner Zeitung, 21 January 2021. https://www.berliner-zeitung.de/news/hahnenschrei-und-schafsbloeken-werden-in-frankreich-kulturerbe-li.134350.

Anon. 2021. France passes sensory heritage law. The Guardian, 21 January 2021. https://www.theguardian. com/world/2021/jan/21/france-passes-sensory-heritage-law-after-plight-of-maurice-the-noisy-rooster.

Appadurai, Arjun. 2020. Foreword: Cultural Mediations and Political Economy. In Cultural Values in Political Economy, ed. J. P. Singh, ix-xi. Stanford: Stanford University Press.

Baumgarten, Alexander Gottlieb. 1961 (1750). Aesthetica: Unveränderter reprographischer Nachdruck der Ausgabe von 1750. Hildesheim: Olms.

Beck, Ulrich. 1997. Was ist Globalisierung? Frankfurt a. M.: Suhrkamp.

Beck, Ulrich, Anthony Giddens, and Scott Lash. 1994. Reflexive Modernization: Politics, Tradition, and Aesthetics in the Modern Social Order. Cambridge: Polity Press.

Bendix, Regina. 2009. Heritage Between Economy and Politics: An Assessment from the Perspective of Cultural Anthropology. In Intangible Cultural Heritage, eds. Laurajane Smith and Natsuko Akagawa, 253-269. London: Routledge.

Bendix, Regina. 2000. The Pleasures of the Ear: Toward an Ethnography of Listening. Cultural Analysis 1. https://www.ocf.berkeley.edu/ culturalanalysis/volume1/vol1_article3.html.

Bendix, Regina, and Orvar Löfgren. 2007. Double Homes, Double Lives? Ethnologia Europaea 37 (1-2): 6-15. DOI: https://doi.org/10.16995/ee.1009.

Diaconu, Madalina. 2013. Phänomenologie der Sinne. Stuttgart: Reclam.

Fraigneau, Victor. 2021. Towards a Sensory Patrimoine?: Atmospheric, Psychological and Ecopolitical Issues on Smell and Sound Identity. Paper presented at the 4th International Congress on Ambiances, Alloaesthesia: Senses, Inventions, Worlds in January 2021. https://www.researchgate.net/publication/348751380_Towards_a_Sensory_Patrimoine_Atmospheric_Psychological_and_Ecopolitical_ Issues_on_Smell_and_Sound_Identity.

Hafstein, Valdimar. 2018. Intangible Heritage as Festival: Or, Folklorization Revisited. Journal of American Folklore 131 (520): 127-148. DOI: https://doi.org/10.5406/jamerfolk.131.520.0127.

Hemme, Dorothee. 2010. Harnessing Daydreams: A Library of Fragrant Fantasies. Ethnologia Europaea 40 (1): 5-18. DOI: https://doi.org/10.16995/ee.1059.

Howes, David. 2019. Multisensory Anthropology. Annual Review of Anthropology 48 (1): 17-28. DOI: https://doi.org/10.1146/annurev-anthro-102218-011324.

Jacka, Jerry K. 2018. The Anthropology of Mining: The Social and Environmental Impacts of Resource Extraction in the Mineral Age. Annual Review of Anthropology 47 (1): 61-77. DOI: https://doi. org/10.1146/annurev-anthro-102317-050156.

Kirshenblatt-Gimblett, Barbara. 1995. Theorizing Heritage. Ethnomusicology 39 (3):367-380. DOI: https:// doi.org/10.2307/924627.

Kepczynska-Walczak, Anetta, and Bartosz Marek Walczak. 2015. Built Heritage Perception through Representation of its Atmosphere. Ambiances: International Journal of Sensory Environment, Architecture and Urban Space 1 (1). DOI: https://doi.org/10.4000/ambiances.640.

Matta, Raúl. 2016. Food Incursions into Global Heritage: Peruvian Cuisine’s Slippery Road to UNESCO. Social Anthropology 24 (3): 338-352. DOI: https://doi.org/10.1111/1469-8676.12300. 
May, Sarah et al., eds. 2017. Taste | Power | Tradition: Geographical Indications as Cultural Property. Göttingen: Göttingen University Press. DOI: https://doi.org/10.17875/gup2017-1004.

Miura, Keiko. 2011. World Heritage Making in Angkor: Global, Regional, National and Local Actors, Interplays and Implications. In World Heritage Angkor and Beyond, ed. Brigitta Hauser-Schäublin, 9-31. Göttingen: Göttingen University Press. DOI: https://doi.org/10.4000/books.gup.304.

Noyes, Dorothy. 2016a. The Judgement of Solomon: Global Protections for Tradition and the Problem of Community Ownership. In Humble Theory: Folklore's Grasp on Social Life, 337-370. Bloomington: Indiana University Press. DOI: https://doi.org/10.2307/j.ctt1zxz0bs.16.

Noyes, Dorothy. 2016b. Heritage, Legacy, Zombie: How to Bury the Undead Past. In Humble Theory: Folklore's Grasp on Social Life, 371-409. Bloomington: Indiana University Press. DOI: https:// doi.org/10.2307/j.ctt1zxz0bs.17.

Projektgruppe Zuhoren, ed. 2003. Über das (Zu-)Hören: Beiträge zur Volkskunde in Niedersachsen 18. Gottingen: Schmerse.

Rfi. 2021. France safeguards rural way of life with 'sensory heritage' law. https://www.rfi.fr/en/ france/20210122-france-safeguards-rural-way-of-life-with-sensory-heritage-law-cow-bells-roosters-noise.

Seidl, Daniela. 2007. Breaking Out into the Everday: German Holiday-Home Owners in Italy. Ethnologia Europaea 37 (1-2): 105-114. DOI: https://doi.org/10.16995/ee.1021.

Silva, Luis. 2014. The Two Opposing Impacts of Heritage Making on Local Communities: Residents' Perceptions: A Portuguese Case. International Journal of Heritage Studies 20 (6): 616-633. DOI: https://doi.org/10.1080/13527258.2013.828650.

Tornatore, Jean-Louis. 2013. Anthropology's Pay-Back: The Gastronomic Meal of the French. In Heritage Regimes and the State, eds. Regina F. Bendix, Aditya Eggert and Arnika Peselmann, 341-365. Göttingen: Göttingen University Press. DOI: https://doi.org/10.4000/books.gup.401.

Urry, John. 1990. The Tourist Gaze: Leisure and Travel in Contemporary Society. London: Sage.

\section{ŽIVLJENJE SAMO: \\ ESEJ O SENZORIČNEM IN (POTENCIALNEM) KONCU USTVARJANJA DEDIŠČINE}

Novi francoski zakon o senzorični dediščini bi labko bil pomemben označevalec v spreminjajoči se dinamiki vrednotenja izbranih vidikov kulture. Vustvarjanju in rabi kulturne dedišcine gre za kompleksno dinamiko, v kateri se gospodarski interesi in kulturne politike, kot sta turistična industrija in konvencije o dediščini, oplajajo iz povečanega (ne le, temveč tudi znanstvenega) zanimanja za prepoznavanje in interpretacijo kulturnih razlik. Sestavni del te dinamike so tudi omejitve, kjer morajo npr. mlini na veter ostati nepozidani, da ne bi pokvarili pogleda na dediščino, ali kjer morajo arhitekti svojo domišljijo uskladiti z Unescovo certificirano dediščino $v$ različnih mestih (Bendix, 2009).

Okvir nesnovne dedišcine je spodbudil in hkrati vznemiril nosilce tradicije, da branijo svoje tradicionalne obrti in praznične dogodke pred nezaželenimi udeleženci ali tatinskimi 
prisvajanji, kar je poleg prizadevanj za vpis dediščine pripeljalo do pravnih in moralnih zadreg, ki v družbene ureditve prinašajo nepredvideno bolečino (Noyes, 2016a).

Sosledje številnih Unescovih mednarodnih konvencij o dediščini od leta 1972 ter številni regionalni in nacionalni instrumenti so senzibilizirali zdravorazumsko dojemanje materialne in nematerialne kulture. Tako je ukvarjanje z dedišcino generiralo izjemno zaposlen kulturni aparat identifikacije, selekcije, nominiranja, upravljanja in varovanja.

$V$ zadnjih desetletjih je prišlo do širitve interesa z materialne dediščine na področje nematerialne, kar kaže na rast refleksivne obravnave polno čutnega. Z ratifikacijo Konvencije o nesnovni dediščini iz leta 2003 so pridobile status dediščine kulturne prakse in zaznave, kiv celoti vključujejo telo in čute: glasbo in ples, pa tudi obrtne tradicije, ki ponazarjajo ročno znanje in spretnost dotika. V Franciji sta pri odkrivanju gastronomske dediščine postala pomembna okus in vonj; na seznamu dediščine je zaokrožila navzočnost čutov v njihovi kulturno oblikovani estetiki. Januarja 2021 so francoski senatorji dokončno odobrili "zakon o čutni dediščini", o čemer je novinar zapisal: "Francosko podeželje je zdaj z zakonom zaščiteno pred poskusi zadušitve vsakdanjih vidikov podeželskega življenja strani prišlekov, ki iščejo mir in tišino [...] Kravji zvončki (in iztrebki), žvrgolenje kobilic ali škržadov in hrupni zgodnji jutranji traktorji zdaj prav tako veljajo za del francoske naravne dedišcine, ki bo zapisana vokoljski zakonodaji« (rfi, 2021).

Tako labko senzorično dediščino ali dediščino čutov razumemo kot zbliževanje med pretirano razsvetljenimi in pretirano kapitalističnimi ljudmi, njihovim vsakdanjim življenjem in ostanki njihove zgodovine. Morda je zdaj odprta pot za ponovno spoznavanje habitusa, torej preprostega ponotranjenja praks vsakdanjega življenja v človeških odnosih in zunaj njih in morda je francoski zakon o čutni dediščini poteza genija, ki nas osvobaja ustvarjanja dediščine.

Prof. Dr. Regina F. Bendix, University of Göttingen, rbendix@gwdg.de 